\title{
Digital Competence of Hospitality Students within the Context of Information and Communication Technology Environment
}

\author{
DSandra Iriste ${ }^{1}$ Dr. paed.; (DIrena Katane ${ }^{2}$ Dr. paed. \\ Latvia University of Life Sciences and Technologies, Latvia \\ sandra.iriste@gmail.com ${ }^{1}$; irena.katane@inbox.lv²
}

\begin{abstract}
In the nearest future, most industries, including hospitality, will be characterized by significant changes linked to the change of business models, leaders break through innovations due to the new global epidemiological situation. Considering the new digitization trends in the hospitality industry, only companies with employees with high-level digital competence will be able to survive, adapt and develop. The dual study environment of a higher education institution - the study environment of a higher education institution and the environment of professional activities plays a major role in the development of digital competence. On the basis of the ecological approach, there has been the context of information and communication technology environment viewed in the article within the substantiation of digital competence. The aim of the study was: during the pedagogical experiment to approbate the developed "Model of the dual study environment of a higher education institution" and to evaluate university hospitality students' competitiveness including digital competence as competitiveness integral part. To find out how significantly has changed the self-evaluation of students' digital competence after the prospective hospitality business managers' competitiveness facilitation in the framework of the developed dual study environmental model. Both before and after the pedagogical experiment the students performed the self-evaluation of digital competence by using the authors' developed and examined competitiveness evaluation methodology. The obtained results testify that the developed and approbated model for promotion of competitiveness development in general impacted self-assessments of the students' digital competence during the pedagogical experiment.
\end{abstract}

Keywords: hospitality business manager, self-evaluation of digital competence, university education.

\section{Introduction}

In nowadays world the development of new technologies is undergoing significant changes. The Paris Communiqué states that digitization should play an increasingly important role in all spheres of society (Paris Communiqué, 2018). It will transform the implementation of higher education at different stages of human life, providing lifelong and flexible learning.

Therefore, the challenge for higher education is to promote prospective specialists to act creatively in the digital environment, develop digital skills and competencies, improve the skills of data analysis and educational research (Zhanguzhinova, Magauova, Nauryzbaeva, 2016; Vronska, 2016; Iriste, Katane, 2019). The interaction of social subjects is largely linked to the growth of mass communications, the use of various types of technology and the role of information in the dual study environment of a higher education institution - the study environment of a higher education institution and the environment of professional activities.

Digitization/integration of digital technologies in the environment of professional activities is becoming an increasingly complex issue for various business areas, including hospitality. The Tourism 4.0 initiative points out that the industry has always been a pioneer in technological development (Stankov, Gretzel, 2020). Digitization changes the way hospitality companies operate, adapting to the information and communication technology (hereafter - ICT) environment in the context of the new global epidemiological situation. The digital competence of hospitality managers is becoming indispensable, especially in the shadow of COVID-19. The authors of the article, based on the ecological approach, substantiate the digital competence of prospective hospitality business managers within the context of communication technology environment.

The aim of the study: during the pedagogical experiment to approbate the developed "Model of the dual study environment of a higher education institution" and to evaluate university hospitality students' competitiveness including digital competence as competitiveness integral part. 


\section{Methodology}

The pedagogical experiment was carried out at the Latvia University of Life Sciences and Technologies, Institute of Education and Home Economics and Nutrition Department of the Faculty of Food Technology. During the pedagogical experiment the model of the dual study environment of a higher education institution was approbated (Figure 1) to promote the development of competitiveness of prospective hospitality business managers.

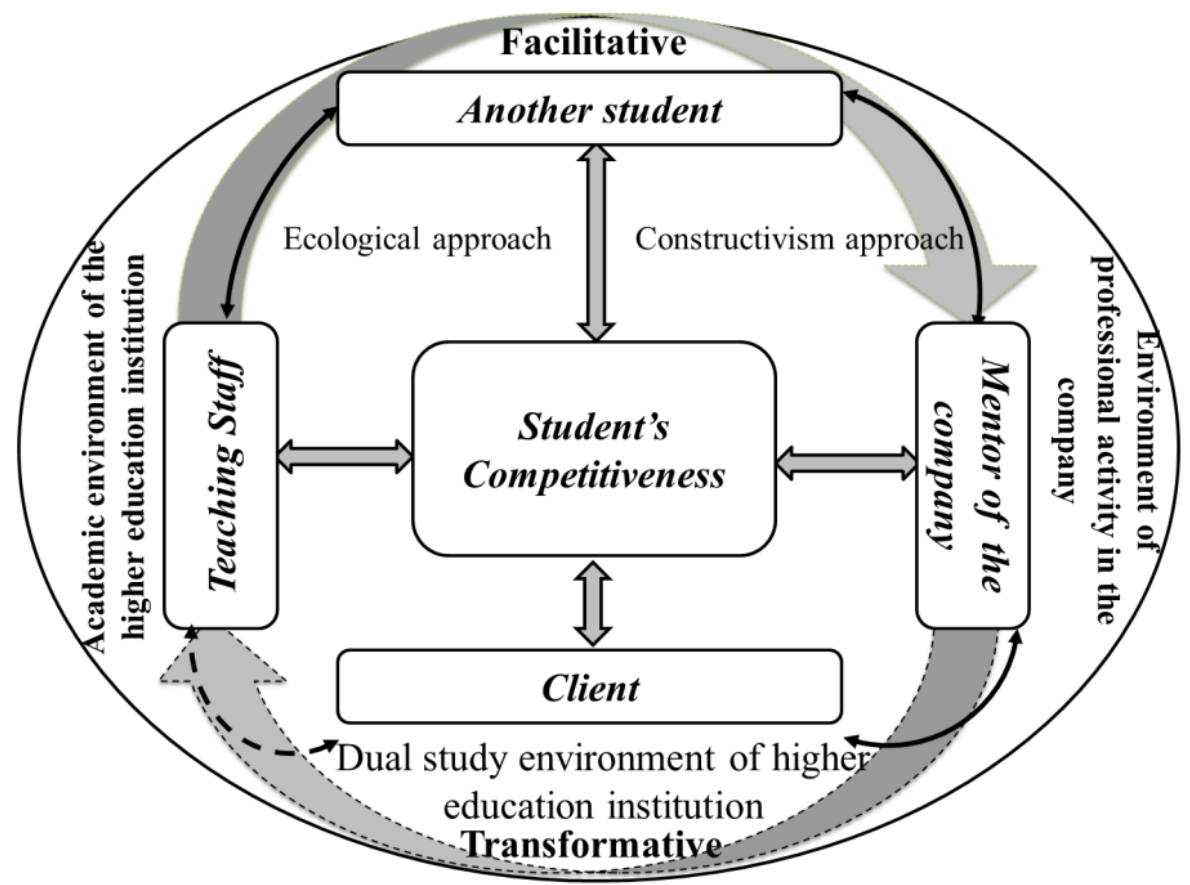

Figure 1. The model of the dual study environment of a higher education institution that transforms and facilitates the development of the competitiveness of prospective hospitality business managers.

To evaluate the impact of the model of the dual study environment of a higher education institution on students' competitiveness development, the model of competitiveness structure (Figure 2) and prospective hospitality business managers' competitiveness self-evaluation methodology were developed (Iriste, Katane, 2015; Iriste, 2018).

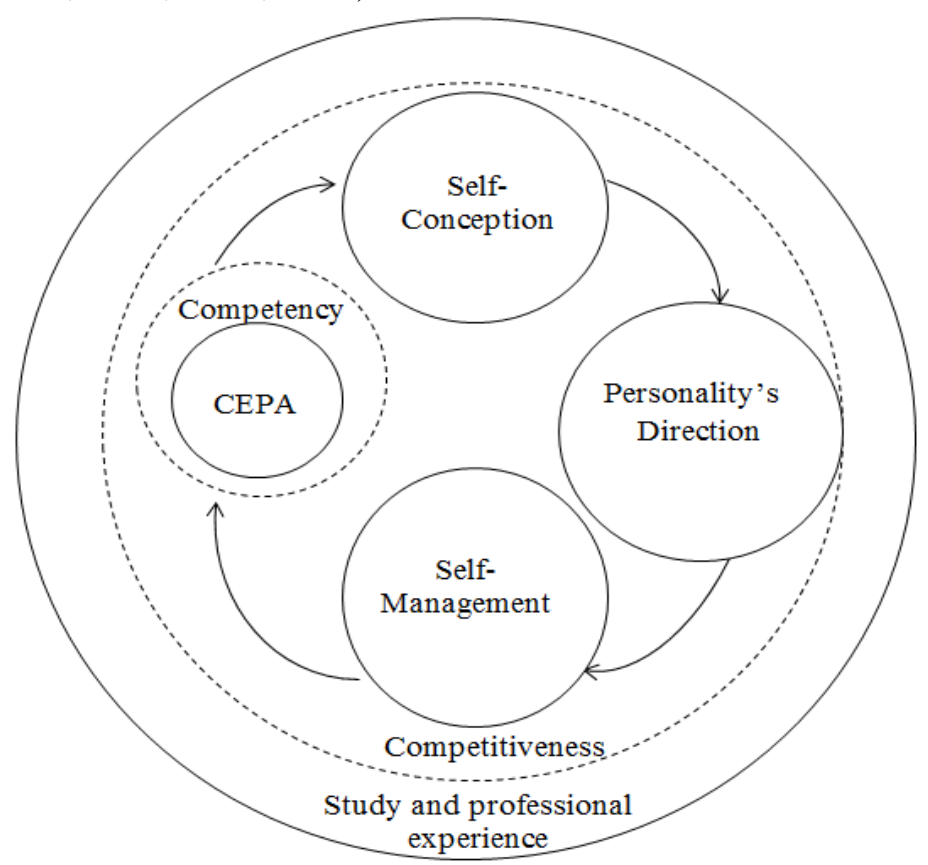

Figure 2. The competitiveness structure model of prospective hospitality business managers. 
Prospective hospitality business managers' competitiveness self-evaluation methodology consists of 203 indicators according to all competitiveness structure model components (Figure 2), where the component of competence of the environment of professional activities (hereafter - CEPA) takes an essential place. An essential integral part of CEPA component is digital competence (Figure 3).

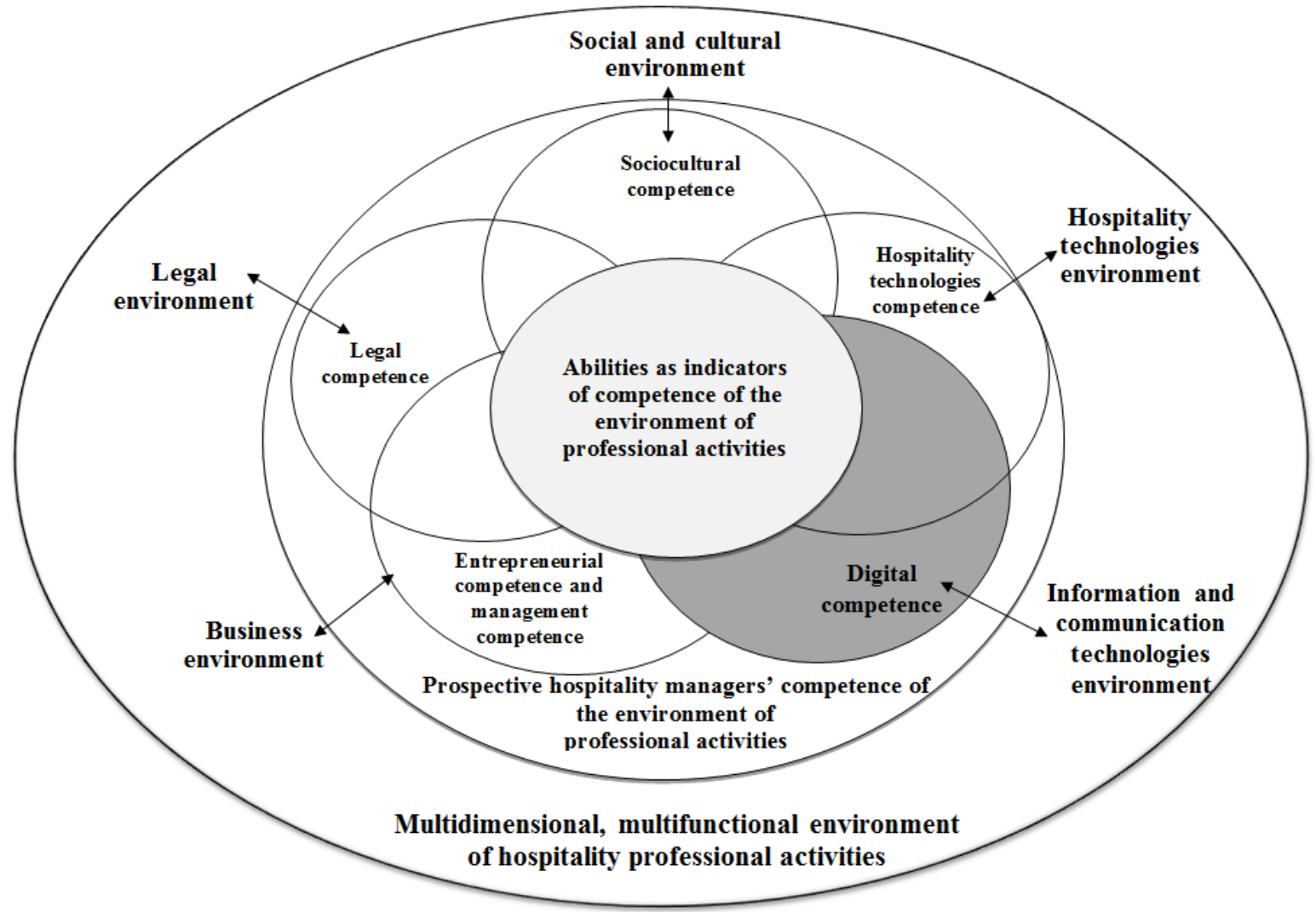

Figure 3. Digital competence in the structure of CEPA of the prospective hospitality business manager.

The methodology for the digital competence self-evaluation of prospective hospitality business managers consisted of 12 indicators that were an integral part of the CEPA evaluation indicators system (in total: 95 indicators).

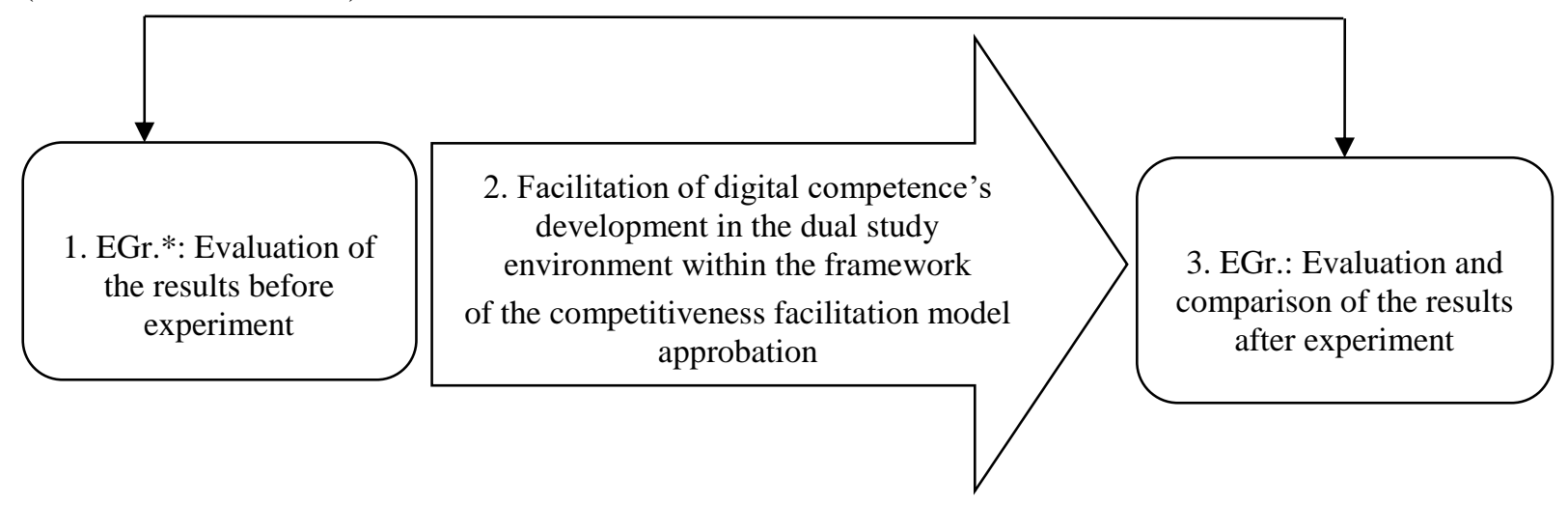

*EGr. - Experimental Group

Figure 4. Pedagogical experiment structure.

In this article the authors publish only results according facilitation and evaluation students' digital competence.

The research question: have there been significant changes in the self-evaluation of the digital competence of prospective hospitality business managers in the process of approbation of the model of the dual study environment of a higher education institution during the pedagogical experiment? 
The model (Figure 1) was implemented in all students' groups and all study courses of the study programme "Catering and Hotel Management" (hereafter-CHM) therefore there was only experimental group in the pedagogical experiment (without control group). It was one of the different types of pedagogical experiment. Fifteen $4^{\text {th }}$ year bachelor students of the study programme " $C H M$ " took part in the pedagogical experiment as an experimental group.

The pedagogical experiment consisted of three stages (Figure 4): 1) the first self-evaluation of the digital competence in the experimental group; 2) facilitation of digital competence's development in the dual study environment within the framework of the model approbation; 3) the second (repeated) self-evaluation of the digital competence in the experimental group and data processing.

The authors used the Wilcoxon Test (SPSS software) to identify differences and to obtain conclusive statistics.

\section{Results and Discussion}

\section{Theoretical basis of the pedagogical experiment}

Digital competence is one of the most important within the competence of the environment of professional activities of the prospective hospitality business manager (Figure 3).

The customers of hospitality companies increasingly prefer face-to-face communication and replace them with various information tools. In this case, the information tool is not just a passive mediator, but a tool for active dialogue between a person and the ICT environment. Therefore, the informative culture of the hospitality staff is crucial, which is essential in the process of personality socialization. One of the main indicators of the existence of informative culture is the ability to use modern technologies in professional activities (Heath, 2012; Semrad et al., 2012), that allows to serve the customer in a 24/7 mode.

According to a study by EHL Swiss School of Tourism and Hospitality (Mamdouh, 2017), one-third $(31 \%)$ of catering managers in Germany, France, Italy and Spain use digital technology in their daily professional activities to promote business processes, $46 \%$ are open and would like to use them, $15 \%$ plan to invest in the implementation of digital technologies in companies. Efficiency and competitiveness of business, as well as the competitiveness of the company as a whole on the Latvian and global hospitality market largely depend on the ability of hospitality managers quickly and efficiently transmit information in the real-time mode. However, $31.4 \%$ of CEOs have a low level of digital competence development (Solis, 2017).

Whereas companies used to hire people to collect data, nowadays they are looking for professionals who can use the Internet and the latest technologies to accumulate, create, analyse, critically assess and share information, secure communicate and collaborate in social networks that is, people with digital competence.

J. Dachis (founder of Razorfish) concluded: all things that can be digitized will be digitized (Dishman, 2011).

Until 1983 digital competence was attributed one of the most insignificant roles in the professional activities of hospitality specialists; however, since the research performed by Institute for the Future analyzes (Davies, Fidler, Gorbis, 2011), it has been named one of the 6 driving forces of changes: 1) growth of smart devices and systems; new technologies will expand, develop human abilities, change work standards; the equipment will also become human collaborators; 2) increase human longevity will completely change the nature of his/her career and education; 3) new media ecology. New communication tools will require new media literacy, which will place new demands on human attention and cognitive processes. While creating an online identity, a person will have to take charge of her or his reputation and identity management; 4) digitalized world. A strong, continuous increase in sensors and processing power will make the world as a programmable system; 5) highly structured organizations, where new social technologies will be transferred to new forms of production and value creation; 6) globally interconnected world. Five of the six identified drivers of change are related to technology.

Companies create databases where the most important information about the wishes, benefits, qualities, etc. of the customer is collected. In the field of hospitality, where a satisfied guest is a guarantee of success in business, there is a growing need for timely and quality information provided by various technologies, 
because (Shariff, Kayat, Abidin, 2014; Sisson, Adams, 2013; Morozov, Morozova, 2009): 1) the information is global in nature; 2) the speed of data collection, processing, storage and transmission increases; 3) the influence of information on the development of various spheres, including tourism and hospitality, is growing; 4) information becomes a product status; 5) different types of technologies become information tools by means of which both communication process and production/creation of a product/service occurs; 6) the decision to purchase a service/product is based on information; 7) the service/product itself is only information at the time of purchase; 8) information is shared by all users in this market.

The impact of information technology in the hospitality industry is vast (Figure 5), so the study environment should facilitate the development of digital competencies of prospective hospitality managers in the rapidly changing and developing hospitality industry (Swanger, Gursoy, 2010). Scientists D. Buhalis and P. O'Connor (2001) have identified three levels of digital competence necessary for those working in the hospitality industry: a) digital competence to use industry applications such as the Fidelio property management software; b) digital competence to use end-user applications, for example Microsoft Word, presentation tools - Microsoft Power Point, online communication tools, planning tools, e-mails - Outlook, Thunderbird; c) digital competence to use conceptual and strategic applications - data collection and processing, planning, modelling, forecasting, optimization and reporting (Nadkarni, 2003). However, there is still a largee gap between the level of competence required by the professional hospitality environment and the level of competence offered by the university environment, which requires cooperation with hospitality companies in organizing and providing internships (Morellato, 2014).

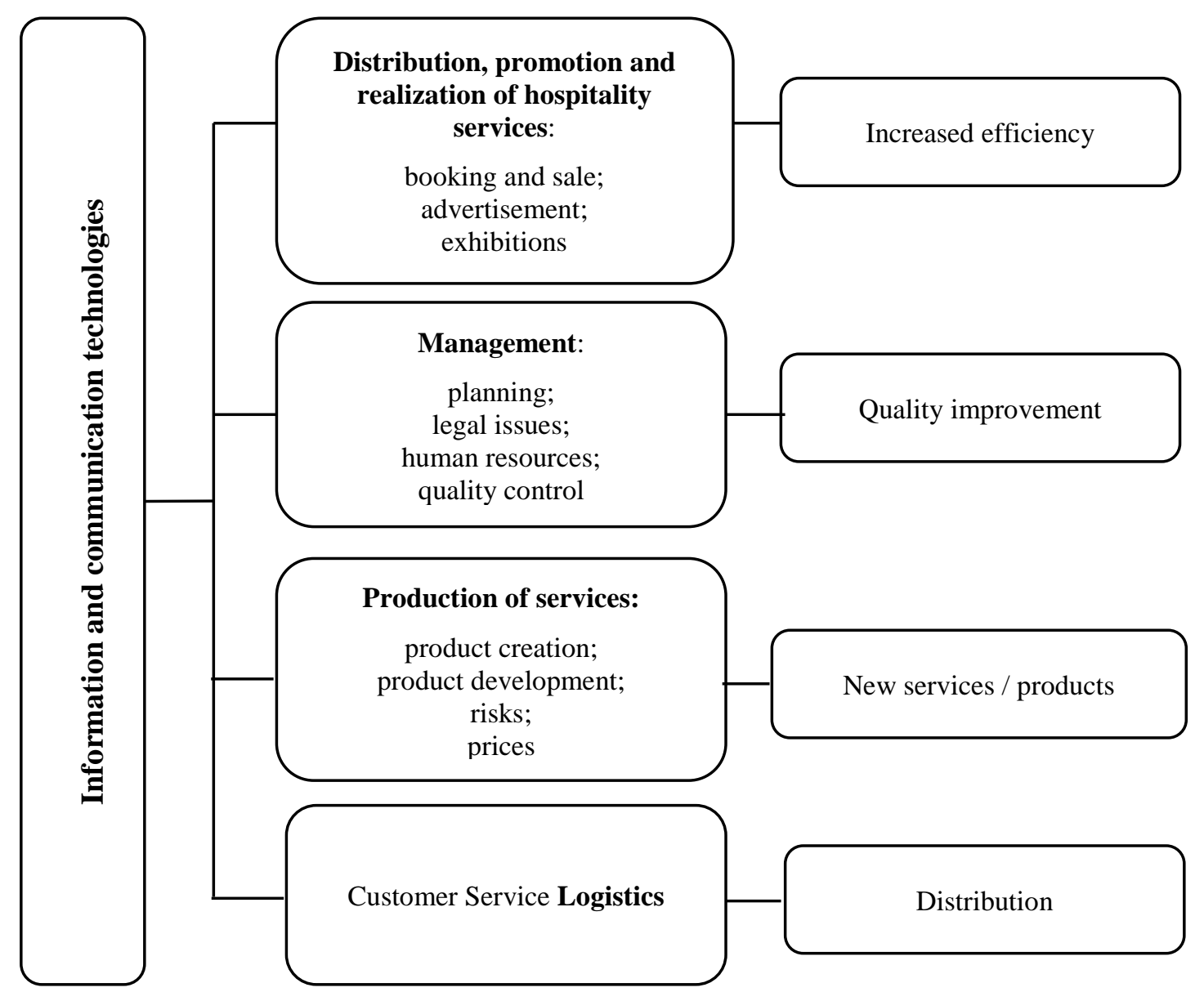

Figure 5. Impact of information and communication technologies in hospitality business

(Source: created, adapted, modified by the authors from Morozov, Morozova, 2009).

In addition to or as a synonym for digital competence (Hölscher, Suchanek, 2011; Zylka, Müller, Martins, 2011), media competence, media literacy is often mentioned in scientific literature, which means the ability to perceive, analyse, structure, evaluate media as well as to create one's own - blogs, podcasts and so on. (Utegenov et al., 2014). As customer service and interpersonal relationships are becoming more digital, prospective hospitality managers are required to be digitally active both with clients and with their 
colleagues through email, various social networking platforms, websites, chat sites, etc. Digital services such as WhatsApp, Lync, Skype, Yammer, etc. are integrated into everyday interpersonal communication.

The ability to find the right one to select relevant information from an unnecessary large amount of information; understanding the principles of social networking is crucial for prospective hospitality managers, because the interaction with the customer, the search for information and making decisions about buying a service/product occurs in today's ICT environment. Thus, the digital competence of hospitality managers is the ability to use, critically analyse, evaluate and transmit different types, formats and categories of multimedia messages, analyse complex information processes and media activities in society to solve various professional tasks in the modern ICT environment (Iriste, 2018; Iriste, Katane, 2015):

- reservations (hotel rooms, tables in the restaurant, tickets, transport, etc.);

- business correspondence through various programs and websites (Outlook, Skype, Twitter, Facebook, TripAdviser, Booking);

- searching for information (including through the software for tourism and hospitality: Amadeus, Galileo International);

- creation and use of customer databases (CRM-systems);

- media awareness.

\section{Pedagogical experiment: results of empirical study}

The first self-evaluation of the digital competence component of the experimental group occurred during the academic year 2018/2019. In the study there was used the competitiveness evaluation methodology, developed by the authors, theoretically grounded, approbated by prospective hospitality managers and expertly evaluated.

Disagree Agree

Figure 6. Projective scale.

Before students completed the questionnaire, they were familiarized with the rules of filling it in. To identify the self-evaluation of digital competence, a scale method was used (Figure 6).

\section{Indicators of digital competence}

Students indicated by slash the extent to which they agree or disagree with the statement.

It took about 10 minutes to complete the questionnaire in the Nutrition department at the Faculty of Food Technology. The first self-evaluation of digital competence was followed by the approbation of the model of the dual study environment of a higher education institution that transforms and facilitates the development of the competitiveness of prospective hospitality business managers. In the final stage of the experiment in September 2019, the experimental group of students repeatedly completed the digital competency self-evaluation questionnaire.

Table 1

Results of the Wilcoxon test: Conclusive statistics 1

\begin{tabular}{|c|l|c|c|c|l|}
\hline $\mathbf{N}$ & \multicolumn{1}{|c|}{$\begin{array}{c}\text { Self-evaluation indicators of digital } \\
\text { competence }\end{array}$} & $\begin{array}{c}\text { Self-evaluation coefficients } \\
\text { Before } \\
\text { experiment }\end{array}$ & $\begin{array}{c}\text { After } \\
\text { experiment }\end{array}$ & p-value & Conclusions \\
\hline 1. & $\begin{array}{l}\text { Ind. } 46 . \text { I know how to choose and apply rational } \\
\text { and effective methods of collecting and } \\
\text { systematizing information to assess the economic } \\
\text { performance of the hospitality enterprise. }\end{array}$ & 0.59 & 0.75 & 0.009 & $\begin{array}{l}\text { Very } \\
\text { significant } \\
\text { differences }\end{array}$ \\
\hline 2. & $\begin{array}{l}\text { Ind. } 48 . \text { I know how to practically use the results } \\
\text { of various studies in a hospitality company. }\end{array}$ & 0.69 & 0.81 & 0.042 & $\begin{array}{l}\text { Significant } \\
\text { differences }\end{array}$ \\
\hline 3. & $\begin{array}{l}\text { Ind. 49. I know how to perceive, analyse, structure } \\
\text { and evaluate the mass media reports. }\end{array}$ & 0.66 & 0.85 & 0.005 & $\begin{array}{l}\text { Very } \\
\text { significant } \\
\text { differences }\end{array}$ \\
\hline 4. & $\begin{array}{l}\text { Ind. 50. I am able to create mass media reports } \\
\text { about what is going on in the hospitality company. }\end{array}$ & 0.50 & 0.73 & 0.011 & $\begin{array}{l}\text { Significant } \\
\text { differences }\end{array}$ \\
\hline
\end{tabular}


The conclusive statistics of the Wilcoxon test shows that after the approbation of competitiveness facilitation model, statistically significant and statistically significant changes (differences) in self-evaluation of the digital competence ( $\mathrm{p}$-value $=0.000 \ldots 0.049$ ) occurred according to 4 indicators: 46, 48, 49, 50 (Table 1).

The results according to 4 indicators $(43,45,51,47)$ testify that differences appear or there is weak coincidence between the self-evaluations of the digital competence of prospective specialists before and after the approbation of the model of dual study environment of a higher education institution. This means that there have been small changes in digital competence self-assessments according to these 4 indicators, but they are not statistically significant. Only 4 indicators $(40,41,42,44)$ show good coincidence and moderate coincidence between self-assessments before and after pedagogical experiment (Table 2).

Table 2

Results of the Wilcoxon test: Conclusive statistics 2

\begin{tabular}{|c|c|c|c|c|c|}
\hline \multirow[b]{2}{*}{$\mathbf{N}$} & \multirow[b]{2}{*}{ Self-evaluation indicators of digital competence } & \multicolumn{2}{|c|}{ Self-evaluation coefficient } & \multirow[b]{2}{*}{$p$-value } & \multirow[b]{2}{*}{ Conclusions } \\
\hline & & $\begin{array}{c}\text { Before } \\
\text { experiment }\end{array}$ & $\begin{array}{c}\text { After } \\
\text { experiment }\end{array}$ & & \\
\hline 1. & $\begin{array}{l}\text { Ind. } 40 \text {. Thanks to various search engines and } \\
\text { technologies, I am able to quickly find, evaluate, } \\
\text { and select the information I need from the global } \\
\text { information network. }\end{array}$ & 0.69 & 0.73 & 0.888 & $\begin{array}{l}\text { Good } \\
\text { coincidence }\end{array}$ \\
\hline 2. & $\begin{array}{l}\text { Ind. } 41 \text {. I am able to work with a large amount of } \\
\text { information by collecting, structuring and archiving it. }\end{array}$ & 0.70 & 0.76 & 0.528 & $\begin{array}{c}\text { Good } \\
\text { coincidence }\end{array}$ \\
\hline 3. & $\begin{array}{l}\text { Ind. } 42 \text {. I am able to summarize the information } \\
\text { received. I am able to develop, complete, and } \\
\text { submit reports on business activities in a timely } \\
\text { manner. I am able to present information, argue. }\end{array}$ & 0.66 & 0.71 & 0.531 & $\begin{array}{l}\text { Good } \\
\text { coincidence }\end{array}$ \\
\hline 4. & $\begin{array}{l}\text { Ind. } 43 \text {. I am able to create and logically present } \\
\text { different structured information elements: reports, } \\
\text { statements, presentations, advertisements using } \\
\text { various media. }\end{array}$ & 0.63 & 0.72 & 0.211 & $\begin{array}{l}\text { Weak } \\
\text { coincidence }\end{array}$ \\
\hline 5. & $\begin{array}{l}\text { Ind. 44. I know how to distance myself from } \\
\text { information that I do not need and is even harmful, } \\
\text { which can negatively affect my professional } \\
\text { activities. }\end{array}$ & 0.68 & 0.79 & 0.259 & $\begin{array}{l}\text { Moderate } \\
\text { coincidence }\end{array}$ \\
\hline 6. & $\begin{array}{l}\text { Ind. } 45 \text {. I am able to work with different types of } \\
\text { information and its storage media, with } \\
\text { spreadsheets and databases. }\end{array}$ & 0.73 & 0.83 & 0.116 & $\begin{array}{l}\text { Weak } \\
\text { coincidence }\end{array}$ \\
\hline 7. & $\begin{array}{l}\text { Ind. 47. I am able to obtain and process the data } \\
\text { necessary for the company's research and } \\
\text { development, including gathering information } \\
\text { from customers to get their opinion. }\end{array}$ & 0.69 & 0.83 & 0.054 & $\begin{array}{l}\text { Differences } \\
\text { appear }\end{array}$ \\
\hline 8. & Ind. 51. I am proficient in document management. & 0.50 & 0.63 & 0.174 & $\begin{array}{c}\text { Weak } \\
\text { coincidence }\end{array}$ \\
\hline
\end{tabular}

Analysing self-evaluation of other indicators of digital competence, already before the pedagogical experiment the coefficients of self-evaluation according to some indicators were high, for example, indicator 41 (0.70), indicator 45 (0.73). However, only for one indicator 51 (I am proficient in document management), it was low: 0.50. If to look at the self-evaluation coefficients, this indicator also has the lowest value after the pedagogical experiment: 0.63 . This indicates that prospective hospitality managers should be offered to take the study course Records Management.

After the pedagogical experiment, 2 indicators (indicator 45 and indicator 47) have very high selfevaluation coefficients (Table 2), which illustrates that young specialists have no difficulties in working with different types of information and its carriers, spreadsheets and databases, as well as know how to receive and process the data necessary for research and development of the company's activities. 
Indicator 44 shows a high level of self-evaluation of competence (0.79) after the pedagogical experiment, which is essential in today's saturated information era.

Hospitality enterprises have the opportunity to expand their target audience, reach and improve service quality, develop at an accelerated pace, considering that the global digitization will be won by those whose arsenal will involve more and better digital platforms and in which employees will feel like fish in the water - that is, have high-level digital competence.

\section{Conclusions}

- The digital competence is one of the most crucial parts of the professional activity competence in the prospective hospitality managers' competitiveness structure. It is the ability to use, critically analyse, evaluate and transmit different types, formats and categories of multimedia messages, analyse complex information processes and media activities in society to solve various professional tasks in the modern ICT environment.

- Comparing the self-assessments of potential hospitality managers according to the 12 indicators of digital competence before and after the pedagogical experiment, the conclusive statistics of the Wilcoxon test (SPSS) shows that there have been statistically significant and statistically significant changes according to 4 indicators $(46,48,49,50)$ of digital competence. The obtained results according to 4 indicators $(43,45,51,47)$ testify that differences appear or there is weak coincidence between the self-evaluations of the digital competence of prospective specialists before and after the approbation of the model of dual study environment of a higher education institution. This means that there have been small changes in digital competence selfassessment according to these 4 indicators, but they are not statistically significant. Only 4 indicators $(40,41,42,44)$ show good coincidence and moderate coincidence between self-assessments before and after pedagogical experiment.

- The obtained results testify that the developed and approbated model for promotion of competitiveness development in general impacted self-assessment of the students' digital competence during the pedagogical experiment. This means that the developed and approbated model transforms and facilitates the development of prospective hospitality business managers' digital competence and in general their competitiveness as well.

- The competitive advantage on the hospitality market will be given to companies in which staff with high-level digital competence work. This is the only way to maintain customer loyalty and business profits, increase innovation and improve security in the changing global environment.

\section{Bibliography}

1. Buhalis D., O'Connor P. (2001). Opinion: IT in the tourism education curriculum. Tedqual/WTO THEMIS Publication, 3(1), 11-14.

2. Davies A., Fidler D., Gorbis M. (2011). Future work skills 2020. Palo Alto, CA: Institute for the Future for the University of Phoenix Research Institute. Retrieved from http://www.iftf.org/uploads/media/SR-1382A_UPRI_future_work_skills_sm.pdf

3. Dishman L. (2011). Innovation Agents: Jeff Dachis, Founder, Dachis Group. Retrieved from https://www.fastcompany.com/1716575/innovation-agents-jeff-dachis-founderdachis-group

4. Heath E. (2012). Shaping responsible future tourism leaders through the key E's tourism educational journey framework. In C. Schott, M. Fesenmaier (Eds.), The Proceedings of the Tourism Education Future Institute 6th Meeting. Milan: Tourism Education Futures Initiative, 100-102. Retrieved from https://www.researchgate.net/publication/283464136_Tourism_Education_Futures_Institute_6th _Annual_Conference_Proceedings_2012_Milan_-

_Transformational_Leadership_for_Tourism_Education

5. Hölscher B., Suchanek J. (2011). Medienkompetenz - Fundament fuer Employability und berufliche Kompetenzdarstellung? In B. Hölscher, J. Suchanek (Eds.), Wissenschaft und Hochschulbildungim Kontext von Wirtschaft und Medien [Science and higher education in the context of business and media]. Wiesbaden: VS Verlag für Sozialwissenschaften, 187-203. doi: 10.1007/978-3-531-926483_11 (in German)

6. Iriste S. (2018). Prospective Managers' of Hospitality Business Competitiveness Evaluation and Development Promotion in the Dual Study Environment of Higher Education Institution. Summary of 
the Doctoral Thesis. Jelgava: LLU. Retrieved from https://llufb.llu.lv/dissertationsummary/pedagogics/Sandra_Iriste_prom_darba_kopsavilkums2018_LLU_IMI.pdf\#page=49

7. Iriste S., Katane I. (2015). Prospective Hospitality Managers Competence as Integral Part of Competitiveness. In V. Dislere (Ed.), The Proceedings of the International Scientific Conference Rural Environment. Education. Personality (REEP), 8. Jelgava: LLU, 42-49. Retrieved from https://lufb.llu.lv/conference/REEP/2015/Latvia-Univ-Agricult-REEP-2015proceedings-42-49.pdf

8. Iriste S., Katane I. (2019). Prospective Hospitality Business Managers' Sociocultural Competence within the Context of Social and Cultural Environments. In V. Dislere (Ed.), The Proceedings of the International Scientific Conference Rural Environment. Education. Personality (REEP), 12. Jelgava: Latvia University of Life Sciences and Technologies, 48-56. doi: 10.22616/REEP.2019.006

9. Mamdouh Sh. (2017). Study: $31 \%$ of restaurateurs use digital technologies - a high potential. Retrieved fromhttps://www.hospitalitynet.org/news/4084535.html

10. Morellato M. (2014). Digital Competence in Tourism Education: Cooperative-experiential Learning. Journal of Teaching in Travel \& Tourism, 14(2), 184-209. doi: 10.1080/15313220.2014.907959

11. Morozov M.A., Morozova N.S. (2009). Informacionnye tehnologii v socialno-kulturnom servise i turizme [Information technologies in social and cultural services and tourism]. Moskva: Akadamiya. (in Russian)

12. Nadkarni S. (2003). Information Technology Competencies in Tourism management Education. Information technology \& Tourism, 6(1), 47-54. doi: 10.3727/109830503108751216

13. Paris Communiqué. (2018). Retrieved from http://www.ehea.info/media.ehea.info/file/2018_Paris/77/1/EHEAParis2018_Communique_final_952771.pdf

14. Semrad K.J., Donohoe H., Thapa B., Tasci A., Stephchenkova S. (2012). Educating the next generation of tourism \& hospitality managers: What core competencies will a globalized industry require from them? In C. Schott, M. Fesenmaier (Eds.), The Proceedings of the Tourism Education Future Institute 6th Meeting, Milan: Tourism Education Futures Initiative, 103-107. Retrieved from https://www.researchgate.net/publication/283464136_Tourism_Education_Futures_Institute_6th_Annual _Conference_Proceedings_2012_Milan_-_Transformational_Leadership_for_Tourism_Education

15. Shariff N.M., Kayat K., Abidin Z.A. (2014). Tourism and hospitality graduates competencies: Industry perceptions and expectations in the Malaysian perspectives. World Applied Sciences Journal, 31(11), 1992-2000. Retrieved from https://www.idosi.org/wasj/wasj31(11)14/22.pdf

16. Sisson L.G., Adams A.R. (2013). Essential hospitality management competencies: the importance of soft skills. Journal of Hospitality \& Tourism Education, 25(3), 131-145. doi: $10.1080 / 10963758.2013 .826975$

17. Solis B. (2017). The 2017 State of Digital Transformation. Retrieved from https://www.linkedin.com/pulse/2017-state-digital-transformation-brian-solis/

18. Stankov U., Gretzel U. (2020). Tourism 4.0 technologies and tourist experiences: a human-centred design perspective. Information Technology \& Tourism, 22, 477-488. doi: 10.1007/s40558-020-00186-y

19. Swanger N., Gursoy D. (2010). An industry-driven model of hospitality curriculum for programs housed in accredited colleges of business: e-assessment tool (e-AT). Journal of Hospitality \& Tourism Education, 22(2), 5-19. doi: 10.1080/10963758.2010.10696972

20. Utegenov Y., Assanova U., Kilybayev K., Uaidullakyzy E., Muzdybayev B., Danabekov E. (2014). Formation of Information and Professional Competence of Primary School Teachers. Life Science Journal, 11(10), 133-140. Retrieved from http://www.lifesciencesite.com/lsj/life1110s/022_25242life1110s14_133_140.pdf

21. Vronska N. (2016). ICT Competences as a Necessary Part of Professional Qualities at the Latvia University of Agriculture. In V. Dislere (Ed.), The Proceedings of the International Scientific Conference Rural Environment. Education. Personality (REEP), 9. Jelgava: LLU, 122-127. Retrieved from https://llufb.llu.lv/conference/REEP/2016/Latvia-Univ-Agricult-REEP2016proceed2255-808X-122-127.pdf

22. Zhanguzhinova M.Y., Magauova A.S., Nauryzbaeva A.S. (2016). Competence Approach in Vocational Education of Kazakhstan in Conditions of Innovational and Industrial Development of the Society. In V. Dislere (Ed.), The Proceedings of the International Scientific Conference Rural Environment. Education. Personality (REEP), 9. Jelgava: LLU, 128-133. Retrieved from https://lufb.llu.lv/conference/REEP/2016/Latvia-Univ-Agricult-REEP-2016proceed2255-808X-128-133.pdf

23. Zylka J., Müller W., Martins S.W. (2011). Media Literacy Worldwide. Similarities and Differences of Theoretical Approaches. The Proceedings of the 2011 IEEE Global Engineering Education Conference (EDUCON), Amman: IEEE, 726-733. doi: 10.1109/EDUCON.2011.5773219 